\title{
Scale up and efficient bioethanol production involving recombinant cellulase (Glycoside hydrolase family 5) from Clostridium thermocellum
}

\author{
Saprativ P Das ${ }^{1 \dagger}$, Deepmoni Deka ${ }^{2 \dagger}$, Arabinda Ghosh ${ }^{1}$, Debasish Das ${ }^{1}$, Mohammad Jawed $^{2}$ and Arun Goyal ${ }^{1,2^{*}}$
}

\begin{abstract}
Background: Lignocellulose degrading fungal enzymes have been in use at industrial level for more than three decades. However, the main drawback is the high cost of the commercially available Trichoderma reesei cellulolytic enzymes.

Results: The hydrolytic performance of a novel Clostridium thermocellum cellulolytic recombinant cellulase expressed in Escherichia coli cells was compared with the naturally isolated cellulases in different modes of fermentation trials using steam explosion pretreated thatch grass and Zymomonas mobilis. Fourier transform infrared (FT-IR) spectroscopic analysis confirmed the efficiency of steam explosion pretreatment in significant release of free glucose moiety from complex lignocellulosic thatch grass. The recombinant GH5 cellulase with $1 \%\left(\mathrm{~W} \mathrm{~V}^{-1}\right)$ substrate and Z. mobilis in shake flask separate hydrolysis and fermentation (SHF) and simultaneous saccharification and fermentation (SSF) trials demonstrated highest ethanol titre $\left(0.99 \mathrm{~g} \mathrm{~L}^{-1}, 1.2 \mathrm{~g} \mathrm{~L}^{-1}\right)$ as compared to Bacillus subtilis $\left(0.51 \mathrm{~g} \mathrm{~L}^{-1}, 0.72 \mathrm{~g} \mathrm{~L}^{-1}\right)$ and Trichoderma reesei $\left(0.67 \mathrm{~g} \mathrm{~L}^{-1}\right.$, $\left.0.94 \mathrm{~g} \mathrm{~L}^{-1}\right)$. A 5\% $\left(\mathrm{W} \mathrm{V}^{-1}\right)$ substrate with recombinant enzyme in shake flask SSF resulted in a 7 fold increment of ethanol titre $\left(8.8 \mathrm{~g} \mathrm{~L}^{-1}\right)$. The subsequent scale up in a $2 \mathrm{~L}$ bioreactor with $1 \mathrm{~L}$ working volume yielded $16.13 \mathrm{~g} \mathrm{~L}^{-1}$ ethanol titre implying a 2 fold upturn. The rotary evaporator based product recovery from bioreactor contributed $94.4\left(\%, \vee \vee^{-1}\right)$ pure ethanol with purification process efficiency of $22.2 \%$.

Conclusions: The saccharification of steam exploded thatch grass (Hyparrhenia rufa) by recombinant cellulase (GH5) along with Z. mobilis in bioethanol production was studied for the first time. The effective pretreatment released substantial hexose sugars from cellulose as confirmed by FT-IR studies. In contrast to two modes of fermentation, SSF processes utilizing recombinant $C$. thermocellum enzymes have the capability of yielding a value-added product, bioethanol with the curtailment of the production costs in industry.
\end{abstract}

Keywords: Bacillus subtilis (B. subtilis), Family 5 Glycoside hydrolase (GH5), Simultaneous saccharification and fermentation (SSF), Trichoderma reesei (T. reesei), Zymomonas mobilis (Z. mobilis), Bioreactor

\section{Background}

Fast depletion of fossil fuel reserves and increasing problem of greenhouse gas effects has stimulated a worldwide interest in alternative, non petroleum-based sources of energy. The use of ethanol as an alternative fuel derived by fermentation process will significantly reduce the consumption of crude oil and eventually the net carbon dioxide emission. The utilization of cheaper substrates such

\footnotetext{
* Correspondence: arungoyl@iitg.ernet.in

${ }^{\dagger}$ Equal contributors

'Department of Biotechnology, Indian Institute of Technology Guwahati, Guwahati 781039, Assam, India

${ }^{2}$ Centre for the Environment, Indian Institute of Technology Guwahati, Guwahati 781039, Assam, India
}

() Chemistry Central

( 2013 Das et al.; licensee Chemistry Central Ltd. This is an Open Access article distributed under the terms of the Creative Commons Attribution License (http://creativecommons.org/licenses/by/2.0), which permits unrestricted use, distribution, and reproduction in any medium, provided the original work is properly cited.

as lignocelluloses and other renewable biomasses would make bio-ethanol more competitive than fossil fuels [1]. Effective pretreatment and efficient hydrolysis of lignocellulosic substrates is the rate limiting step towards techno-economical feasibility of lignocellulosic ethanol fermentation. Electron microscopy and fourier transform infrared (FT-IR) spectroscopy have been used for the analysis of structural and morphological modifications in the biomass after pretreatment [2-5]. The hydrolytic activity of cellulases with the maximum release of utilizable sugars is a crucial factor in bioethanol production. With respect to various pretreatments, the utility of enzymatic hydrolysis with the aid of microbes has many advantages such as less usage of energy, no release of toxic chemicals 
and diminished generation of products lethal to the environment as well as mankind. The prime hindrance in the usage of commercial fungal enzymes is, lies in its high cost. Also, there is absence of prominent $\beta$-glucosidase activity in most of the readily available enzymatic pools, directed towards an efficient saccharification process [6]. Bacterial cellulases are also potential candidates as they can withstand harsh conditions such as high temperature, sugar, salt and ethanol concentrations during lignocellulose degradation and can metabolize wide range of sugars improving the process of ethanol production [7]. Bacillus subtilis (AS3) produce cellulases which are alkaline, thermostable, show wide range of $\mathrm{pH}$ stability and substrate specificity for both soluble and crystalline substrates such as avicel [8]. The optimum temperature for cellulase activity of $B$. subtilis (AS3) is close to that of recombinant and fungal cellulase [8]. The cellulosome of Clostridium thermocellum is known to have one of the highest rates of cellulose utilization till date reported, that displays 50 -fold higher specific activity than the corresponding Trichoderma reesei system against crystalline cellulose [9]. The recombinant cellulase isolated from E. coli BL21 cells transformed with full length gene CtLic26A-GH5CBM11 from Clostridium thermocellum was shown to have better cellulolytic activity in an efficient SSF process using Jamun (Syzygium cumini) leafy biomass as the substrate [10].

In simultaneous saccharification and fermentation (SSF) process, the enzymatic hydrolysis of cellulose and the fermentation of monomeric sugars are performed in a single step, making the process a beneficial alternative to separate hydrolysis and fermentation (SHF) [11]. The key enzymes for ethanol fermentation: alcohol dehydrogenase and pyruvate decarboxylase was reported to be best expressed in Zymomonas mobilis [12,13]. As a consequence, in recent years, research is focused on Z. mobilis, as promising alternative ethanol producer because of its high glucose uptake and high ethanol tolerance. The rotary vaccum evaporation, distillation and pervaporation are frequently used for retrieval of various fermentation products [14].

In the present study, the hydrolytic performance of a novel recombinant cellulolytic cellulase was compared with the performance of fungal and naturally isolated bacterial cellulase employing various modes of lignocellulosic ethanol formation by $Z$. mobilis from steam exploded thatch grass (H. rufa) for the first time. The breakdown of structural carbohydrates by steam explosion was assessed by Fourier transform infrared (FT-IR) spectroscopy studies. The hydrolytic efficiency of various cellulolytic enzymes was assessed by obtaining dynamic profile of growth of $Z$. mobilis as fermentative microbe, release of reducing sugar, ethanol titre and specific activity of the enzymes in several SHF and SSF combinations at shake flask level. Further, shake flask SSF experiment with increased substrate concentration was scaled up to a laboratory scale bioreactor under controlled process parameters of $\mathrm{pH}$, temperature, aeration and agitation following ethanol recovery.

\section{Results and discussion}

\section{Structural carbohydrates determination}

Increment in the efficiency of hydrolysis is the main purpose of using pretreatment methods for lignocellulosic substrates. Steam explosion pretreatment was employed for delignification to increase the efficiency of hydrolysis of lignocellulosic biomass, thatch grass. The carbohydrate analysis of untreated thatch grass (Hyparrhenia rufa) exhibited $\left(\mathrm{w} \mathrm{w}^{-1}\right)$ cellulose $(45.07 \%)$, hemicellulose (29.06\%) and lignin (17.43\%) whereas pretreated substrate showed cellulose (41.02\%), hemicellulose $(28.14 \%)$ and lignin (14.19\%). Various lignocellulosic biomasses such as bermudagrass, reed and rapeseed were reported to have cellulose content of $27 \%-49 \%$ and lignin content of $18 \%$ $24 \%$ [15], respectively which are similar to the cellulose content of thatch grass substrate used in the present study. The abrupt depressurization in the pretreatment helped to release maximum amount of reducing sugars in least pretreatment time. The FESEM images for steam exploded thatch grass showed the increment in porosity and structural destabilization of the lignocellulosic complex as compared to the untreated thatch grass sample (Figure 1A and 1B). The accessibility of the enzyme to the cellulosic contents of the substrate was increased by change in structure and increase in porosity showing an effective pretreatment process in biofuel production from lignocellulosic leafy residues. In the preliminary experiments, an ethanol titre of $0.92 \mathrm{~g} \mathrm{~L}^{-1}$ was obtained with untreated thatch grass as compared to the higher titre value of $1.2 \mathrm{~g} \mathrm{~L}^{-1}$ with steam exploded thatch grass. Thus, steam explosion proved to be an efficient pretreatment method as shown by the composition analysis of the sugars present in the substrate and ethanol titre before and after the pretreatment strategy.

\section{FT-IR spectroscopy analysis}

The FT-IR spectral analysis of both untreated and pretreated thatch grass samples were carried out (Figure 2). The $\mathrm{H}$-bond transmittance of $\mathrm{OH}$ stretching supposed to arise from the glycosidic bonds of cellulose or hydroxyphenyl, guaiacyl and syringyl groups of lignin released from pretreated thatch grass was shifted to higher wave number from $3416 \mathrm{~cm}^{-1}$ to $3426 \mathrm{~cm}^{-1}$ in the treated sample (Figure 2). The analysis of carbohydrate specific fingerprint of FT-IR spectra obtained is depicted in Table 1. The shift was due to change of hydrogen bonding energy in the system of internal and intermolecular interactions [16]. Two independent peaks at 2967 and $2900 \mathrm{~cm}^{-1}$ appeared in pretreated sample due to $\mathrm{C}-\mathrm{H}$ stretching of aliphatic structures as also reported by Cao and Tang [17]. In contrast, a less pronounced single peak at $2934 \mathrm{~cm}^{-1}$ 

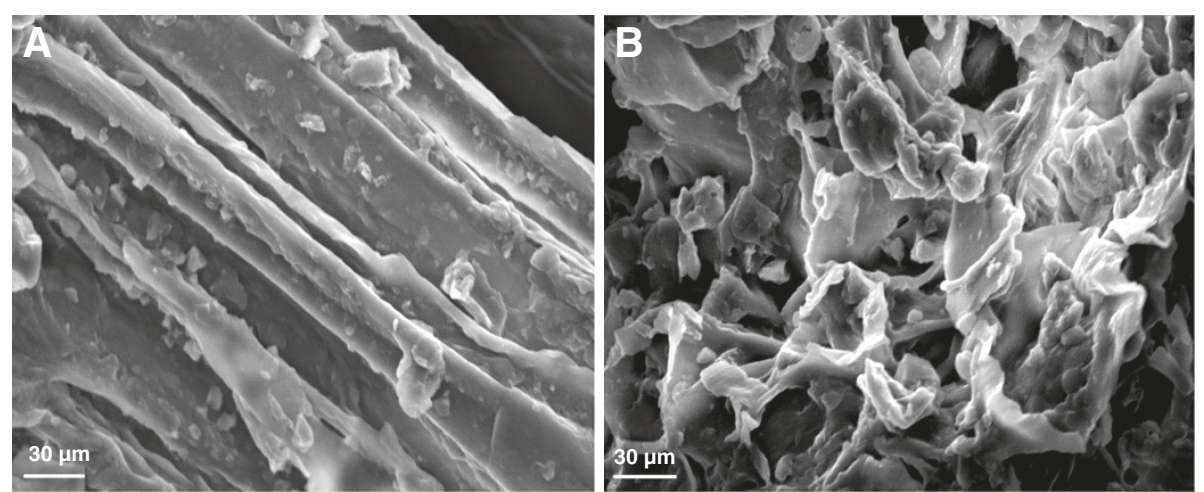

Figure 1 FESEM images. A) Untreated thatch grass B) Steam exploded thatch grass. Topological changes associated with steam explosion pretreatment are clearly detectable. All images are shown at same magnification-scale bar: $30 \mu \mathrm{m}$.

was observed in the untreated sample. A little lignin component was detected after pretreatment. The band at $1628 \mathrm{~cm}^{-1}$ appeared due to the aromatic ring stretch of lignin component, a similar analysis was reported earlier [18]. $1596 \mathrm{~cm}^{-1}$ band appeared for aromatic skeletal vibration plus $\mathrm{C}=\mathrm{O}$ stretch. A band at $1160 \mathrm{~cm}^{-1}$ was due to the anti-symmetric bridge stretching of $\mathrm{C}_{-}$ $\mathrm{O}-\mathrm{C}$ groups in cellulose and hemicellulose. The shift of $1383 \mathrm{~cm}^{-1}$ peak of untreated sample to $1318 \mathrm{~cm}^{-1}$ in pretreated sample could be attributed to $\mathrm{CH}_{2}$-wagging vibrations in cellulose and hemicellulose. Similar peaks have been observed while analyzing the FT-IR spectra of cellulose from eucalyptus pulp by enzymatic hydrolysis [18]. Several research groups proposed different peak pairs for crystalline and amorphous cellulose viz., $1430 \mathrm{~cm}^{-1}$ for crystalline and $893 \mathrm{~cm}^{-1}$ for amorphous cellulose [19]. In our present study, the pretreated thatch grass displayed

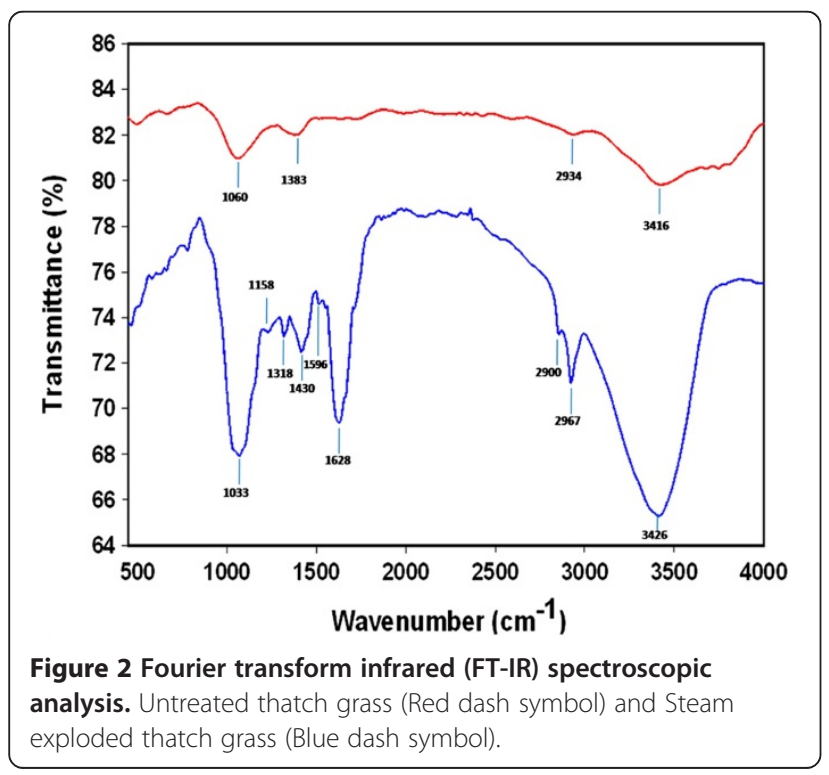

a $1430 \mathrm{~cm}^{-1}$ peak which was due to crystalline cellulose but no peak for amorphous form was observed. A more contrasting peak was observed at lower wavenumber $1033 \mathrm{~cm}^{-1}$ as compared to untreated sample at $1060 \mathrm{~cm}^{-1}$ which arose due to $\mathrm{C}$ - $\mathrm{O}$ stretch vibration of glucose from cellulose hydrolysis in the pretreated sample. Glucose is reported to give maximum peak intensity at $1033 \mathrm{~cm}^{-1}$ due to $\mathrm{C}-\mathrm{O}$ stretch vibration [20]. Therefore, the steam explosion pretreatment process was significant in the release of free sugars such as glucose moiety from thatch grass for cellulosic fermentation to ethanol.

\section{SHF at shake flask level}

The hexose utilizing Zymomonas mobilis was employed as an alternative ethanol producer over conventional microbes in SHF trials with $1 \%\left(\mathrm{w} \mathrm{v}^{-1}\right)$ steam explosion pretreated thatch grass. Z. mobilis is reported to possess the key enzymes, alcohol dehydrogenase and pyruvate decarboxylase assisting in high sugar uptake with improved ethanol yield, enhanced ethanol tolerance and lesser biomass production [13]. The first SHF experiment with $B$. subtilis cellulase and $Z$. mobilis contributed a reducing sugar concentration of $0.84 \mathrm{~g} \mathrm{~L}^{-1}$, an ethanol titre and yield

Table 1 Assignment of functional groups FTIR bands in lignocellulosic biomass samples

\begin{tabular}{lc}
\hline Name of characteristic group & Wavenumber $\left(\mathbf{c m}^{-1}\right)$ \\
\hline $\mathrm{OH}$ & 3426 \\
Aliphatic C-H stretch & 2967,2900 \\
Aromatic ring stretch of lignin & 1628 \\
Aromatic skeletal vibration plus C=O stretch & 1596 \\
$\mathrm{CH}_{2}$-wagging vibrations in cellulose and & 1318 \\
hemicellulose & \\
Anti-symmetric bridge stretching of & 1160 \\
C-O-C groups in cellulose and hemicellulose & \\
C-H (Crystalline cellulose) & 1430 \\
C - O stretch vibration of Glucose & 1033 \\
\hline
\end{tabular}


of $0.51 \mathrm{~g} \mathrm{~L}^{-1}$ and $0.051 \mathrm{~g}$ of ethanol $\mathrm{g}$ of substrate ${ }^{-1}$ respectively (Table 2). The second SHF trial with $T$. reesei cellulase and Z. mobilis offered reducing sugar $\left(0.98 \mathrm{~g} \mathrm{~L}^{-1}\right)$, ethanol titre of $0.67 \mathrm{~g} \mathrm{~L}^{-1}$ with a yield co-efficient of $0.067 \mathrm{~g}$ of ethanol $g$ of substrate ${ }^{-1}$ (Table 2). Interestingly, the final SHF test with crude recombinant cellulase (GH5) and $Z$. mobilis provided a maximum ethanol concentration of $0.99 \mathrm{~g} \mathrm{~L}^{-1}$, reducing sugar content of $1.21 \mathrm{~g} \mathrm{~L}^{-1}$ and an improved yield co-efficient of $0.099 \mathrm{~g}$ of ethanol $\mathrm{g}$ of substrate $^{-1}$ (Table 2). Being a part of C. thermocellum cellulosome, the recombinant GH5 cellulase expressed in $E$. coli cells had effective cellulose conversion. This was envisaged from released reducing sugar by GH5 cellulase giving an improved ethanol titre as compared to naturally isolated B. subtilis and T. reesei cellulases (Table 2).

\section{SSF at shake flask level}

In the first SSF combination involving B. subtilis cellulase and $Z$. mobilis using thatch grass, the dynamic profile showed an increment of cell OD in a sigmoidal manner attaining a maximum of 0.76 at $60 \mathrm{~h}$ of fermentation. There was a marginal decrease in reducing sugar reserve albeit no production of ethanol after $24 \mathrm{~h}$ of fermentation owing to its utilization for growth and metabolism by Zymomonas. After $24 \mathrm{~h}$, a gradual increase in ethanol concentration was observed over the incubation period with simultaneous decrease in total sugar (Figure 3). The release of reducing sugars of $1.10 \mathrm{~g} \mathrm{~L}^{-1}$ and ethanol concentration of $0.72 \mathrm{~g} \mathrm{~L}^{-1}$ was obtained after $72 \mathrm{~h}$ of fermentation (Table 3, Figure 3). An ethanol yield ( $g$ of ethanol $g$ of substrate ${ }^{-1}$ ) of 0.072 was obtained. The second SSF combination involving $T$. reesei cellulase and $Z$. mobilis yielded reducing sugars of $1.10 \mathrm{~g} \mathrm{~L}^{-1}$, ethanol concentration of $0.94 \mathrm{~g} \mathrm{~L}^{-1}$ and ethanol yield ( $\mathrm{g}$ of ethanol $\mathrm{g}$ of substrate ${ }^{-1}$ ) of 0.094 (Table 3).

In case of final SSF combination involving recombinant cellulase (GH5) and Zymomonas mobilis for fermentation (Figure 4), Z. mobilis exhibited two distinct growth phases implying diauxic growth kinetics. The first growth phase corresponded to an initial $18 \mathrm{~h}$ of fermentation with an average specific growth rate $\left(\mu_{m}\right)$ of $0.4 \mathrm{~h}^{-1}$. During this phase, the utilization of sugar produced from the hydrolysis of substrate by the enzyme was used by the microorganism for its growth. The second distinct growth phase was observed during $48-60 \mathrm{~h}$ of fermentation with a

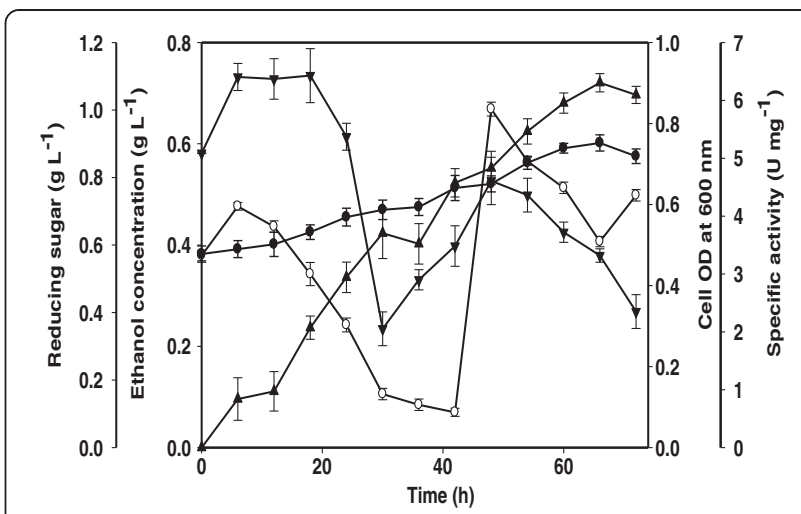

Figure $3 \mathrm{SSF}$ profile of $1 \%\left(w v^{-1}\right)$ thatch grass using bacterial cellulase, $\boldsymbol{Z}$. mobilis in shake flask. The cultivation conditions were $100 \mathrm{~mL}$ working volume in $250 \mathrm{~mL}$ Erlenmeyer flask; initial pH 4.3; temperature $30^{\circ} \mathrm{C}$; shaking $120 \mathrm{rpm}$. $(\bullet)$ cell OD measured at 600 $\mathrm{nm},(\boldsymbol{\Lambda})$ ethanol concentration $\left(\mathrm{g} \mathrm{L}^{-1}\right),(\boldsymbol{\nabla})$ reducing sugar $\left(\mathrm{g} \mathrm{L}^{-1}\right)$ and (o) specific activity $\left(\mathrm{U} \mathrm{mg}^{-1}\right)$ with time $(\mathrm{h})$.

maximum specific growth rate $\left(\mu_{m}\right)$ of $0.4 \mathrm{~h}^{-1}$. The biomass production reached its peak value $\left(\mathrm{A}_{600 \mathrm{~nm}} 0.8\right)$ at 60 $\mathrm{h}$ of fermentation, and the growth rate remained constant for rest of the fermentation process, indicating achievement of senescence. The ethanol formation was proportional to the increase in biomass. A maximum ethanol titre of $1.2 \mathrm{~g} \mathrm{~L}^{-1}$ was achieved (Table 3, Figure 4) at $60 \mathrm{~h}$ of fermentation and after that it remained constant. The ethanol yield ( $\mathrm{g}$ of ethanol $\mathrm{g}$ of substrate $^{-1}$ ) obtained was 0.120 (Table 3). Interestingly, the dynamic profile of reducing sugar showed a sinusoidal behaviour which can be attributed to a delicate balance between the rate of saccharification for release of reducing sugar and the rate of its subsequent utilization for growth and ethanol formation. It is important to note that the increase in reducing sugar concentration $\left(1.45 \mathrm{~g} \mathrm{~L}^{-1}\right)$ was found to be concomitant with decrease in specific activity of enzyme and vice-versa. The ethanol titre $\left(\mathrm{g} \mathrm{L}^{-1}\right)$ obtained from various SSF experiments involving pretreated thatch grass clearly proved SSF process better over SHF with enhanced ethanol yields by eliminating end product inhibition and excluding separate reactors' obligation. Similar findings are reported in literature [11]. The bioreactor scale up was employed for the best SSF combination involving recombinant cellulase $(\mathrm{GH} 5)$ and $Z$. mobilis in terms of reducing sugar concentration and ethanol value.

Table 2 SHF with steam exploded thatch grass involving various hydrolytic enzymes and Zymomonas mobilis

\begin{tabular}{|c|c|c|c|c|}
\hline SSF combination & $\begin{array}{l}\text { Substrate concentration } \\
\left(w v^{-1}\right) \text { and Mode of SSF }\end{array}$ & Reducing sugar $\left(\mathrm{g} \mathrm{L}^{-1}\right)^{*}$ & $\begin{array}{l}\text { Ethanol yield ( } g \text { of ethanol } \\
g \text { of untreated substrate }{ }^{-1} \text { ) }\end{array}$ & Ethanol titre $\left(\mathrm{g} \mathrm{L}^{-1}\right)^{*}$ \\
\hline Bacillus subtilis cellulase & 1\% Shake flask & $0.84 \pm 0.05$ & 0.051 & $0.51 \pm 0.03$ \\
\hline Trichoderma reesei cellulase & $1 \%$ Shake flask & $0.98 \pm 0.06$ & 0.067 & $0.67 \pm 0.07$ \\
\hline Recombinant cellulase (GH5) & 1\% Shake flask & $1.21 \pm 0.04$ & 0.099 & $0.99 \pm 0.02$ \\
\hline
\end{tabular}

"the values correspond to the maximum reducing sugar and maximum ethanol titre at a particular time. Values are mean $\pm S E(n=3)$. 
Table 3 SSF with steam exploded thatch grass involving various hydrolytic enzymes and Zymomonas mobilis

\begin{tabular}{|c|c|c|c|c|}
\hline SSF combination & $\begin{array}{l}\text { Substrate concentration } \\
\left(w v^{-1}\right) \text { and Mode of SSF }\end{array}$ & Reducing sugar $\left(\mathrm{g} \mathrm{L}^{-1}\right)^{*}$ & $\begin{array}{l}\text { Ethanol yield ( } \mathrm{g} \text { of ethanol } \\
\mathrm{g} \text { of untreated substrate }{ }^{-1} \text { ) }\end{array}$ & Ethanol titre $\left(\mathrm{g} \mathrm{L}^{-1}\right)^{*}$ \\
\hline Bacillus subtilis cellulase & $1 \%$ Shake flask & $1.10 \pm 0.02$ & 0.072 & $0.72 \pm 0.02$ \\
\hline Trichoderma reesei cellulase & $1 \%$ Shake flask & $1.10 \pm 0.07$ & 0.094 & $0.94 \pm 0.05$ \\
\hline Recombinant cellulase (GH5) & $1 \%$ Shake flask & $1.45 \pm 0.03$ & 0.120 & $1.20 \pm 0.03$ \\
\hline Recombinant cellulase (GH5) & $5 \%$ Shake flask & $12.10 \pm 0.04$ & 0.180 & $8.79 \pm 0.04$ \\
\hline Recombinant cellulase (GH5) & $5 \%$ Bioreactor & $18.98 \pm 0.04$ & 0.320 & $16.13 \pm 0.03$ \\
\hline
\end{tabular}

"the values correspond to the maximum reducing sugar and maximum ethanol titre at a particular time.

Values are mean \pm SE $(n=3)$.

SSF involving recombinant cellulase (GH5) and $Z$. mobilis using $5 \%\left(\mathrm{w} \mathrm{v}^{-1}\right)$ thatch grass in shake flask and bioreactor It is well known that a rise in substrate concentration along with enzyme loadings and inoculum size has a significant acceleration in ethanol titre. Accordingly, the shake flask batch SSF was performed using a substrate concentration of $5 \%\left(\mathrm{w} \mathrm{v}^{-1}\right)$ alongwith recombinant cellulase (GH5) and $Z$. mobilis. The recombinant cellulase (GH5) and Z. mobilis yielded ethanol concentration of $8.79 \mathrm{~g} \mathrm{~L}^{-1}$ with a maximum released reducing sugar of $12.1 \mathrm{~g} \mathrm{~L}^{-1}$ (Table 3). The yield of ethanol ( $\mathrm{g}$ of ethanol $\mathrm{g}$ of substrate ${ }^{-1}$ ) obtained was 0.180 (Table 3).

In general, it is possible to tightly regulate the important process parameters in an automated bioreactor. It is important to note that the parameters such as $\mathrm{pH}$ and aeration will have significant effect on fermentation dynamics and hence, final ethanol titre. To that end, the SSF was further scaled up in the bioreactor. Unlike shake flask, a single growth phase was observed instead of diauxic growth. The cell OD initially remained low followed by an exponential increase to a maximum value of $\left(\mathrm{A}_{600 \mathrm{~nm}} 7.0\right)$ at $66 \mathrm{~h}$ of fermentation (Figure 5). The dynamic profile of reducing sugar showed a substantial accumulation in the initial phase of fermentation (18.98 $\mathrm{g} \mathrm{L}^{-1}$ at $18 \mathrm{~h}$ ), followed by

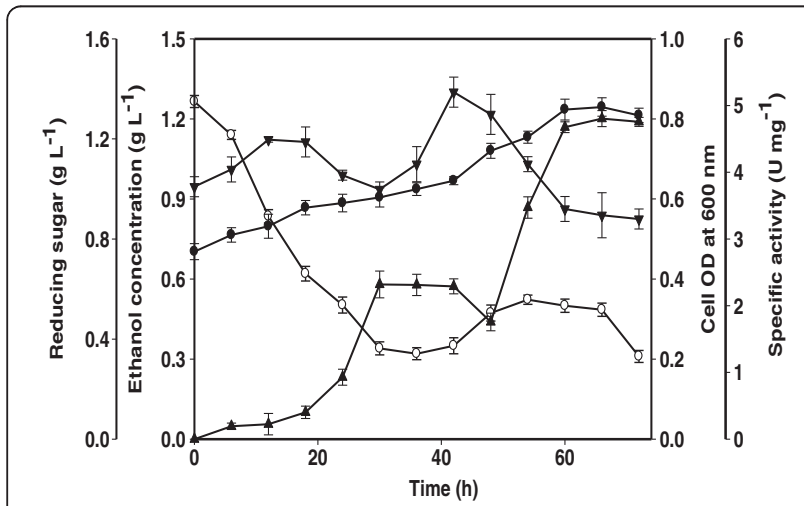

Figure 4 SSF profile of $1 \%\left(w v^{-1}\right)$ thatch grass using GH5 cellulase, $\boldsymbol{Z}$. mobilis in shake flask. The cultivation conditions were $100 \mathrm{~mL}$ working volume in $250 \mathrm{~mL}$ Erlenmeyer flask; initial pH 4.3; temperature $30^{\circ} \mathrm{C}$; shaking $120 \mathrm{rpm}$. (•) cell OD measured at $600 \mathrm{~nm}$, $(\boldsymbol{\Delta})$ ethanol concentration $\left(\mathrm{g} \mathrm{L}^{-1}\right),(\boldsymbol{\nabla})$ reducing sugar $\left(\mathrm{g} \mathrm{L}^{-1}\right)$ and $(\mathrm{o})$ specific activity $\left(U \mathrm{mg}^{-1}\right)$ with time $(\mathrm{h})$. a sharp decrease in concentration concomitant with exponential phase of growth (Table 3, Figure 5). The saccharification products released from complex polysaccharide content of thatch grass in bioreactor SSF were detected by HPAEC-PAD by comparing the retention time of standard monosaccharide sugars (Figures 6A, B, C, D, E and F). The $0 \mathrm{~h}$ HPAEC profile of monosaccharides depicted small amount of xylose that might have been released along with glucose during steam explosion pretreatment (Figure 6B). Surprisingly, the same amount of xylose was revealed in the later stages of SSF as Z. mobilis utilizes strictly hexose sugars (Figures 6C, D, E and F). The $18 \mathrm{~h}$ HPAEC profile exhibited considerable amount of glucose released by recombinant $C$. thermocellum cellulase (GH5) (Figure 6C). The HPAEC profile sensed a gradual decrease in glucose at $36 \mathrm{~h}$ (Figure 6D) and 54 h (Figure 6E) due to its utilization by $Z$. mobilis. Lastly, the $72 \mathrm{~h}$ HPAEC pattern presented negligible amount of glucose owing to its consumption by $Z$. mobilis for growth, maintenance and ethanol formation (Figure 6F). It is to be noted that rate of ethanol formation (16.13 $\mathrm{g} \mathrm{L}^{-1}$ ) was found to be proportional with the rate of substrate utilization and cell population growth (Table 3, Figure 5). The ethanol yield obtained was 0.320 (g of

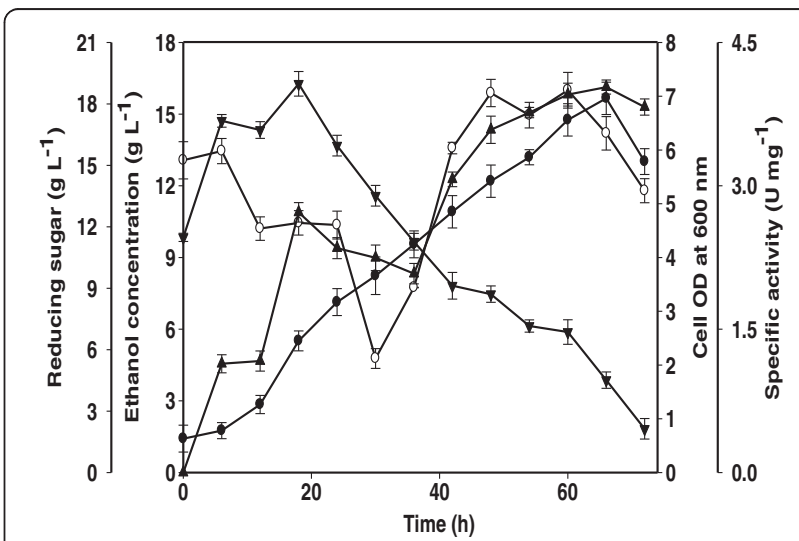

Figure 5 SSF profile of $5 \%\left(w^{-1}\right)$ thatch grass using GH5 cellulase, $\boldsymbol{Z}$. mobilis in bioreactor. The cultivation conditions were $1 \mathrm{~L}$ working volume in a $2 \mathrm{~L}$ lab scale bioreactor; aeration rate 1 vvm; pH 4.3; temperature $30^{\circ} \mathrm{C}$; agitation $120 \mathrm{rpm}$. $(\bullet)$ cell $\mathrm{OD}$ measured at $600 \mathrm{~nm},(\boldsymbol{\Delta})$ ethanol concentration $\left(\mathrm{g} \mathrm{L}^{-1}\right),(\boldsymbol{\nabla})$ reducing sugar $\left(\mathrm{g} \mathrm{L}^{-1}\right)$ and $(0)$ specific activity $\left(U \mathrm{mg}^{-1}\right)$ with time $(\mathrm{h})$. 

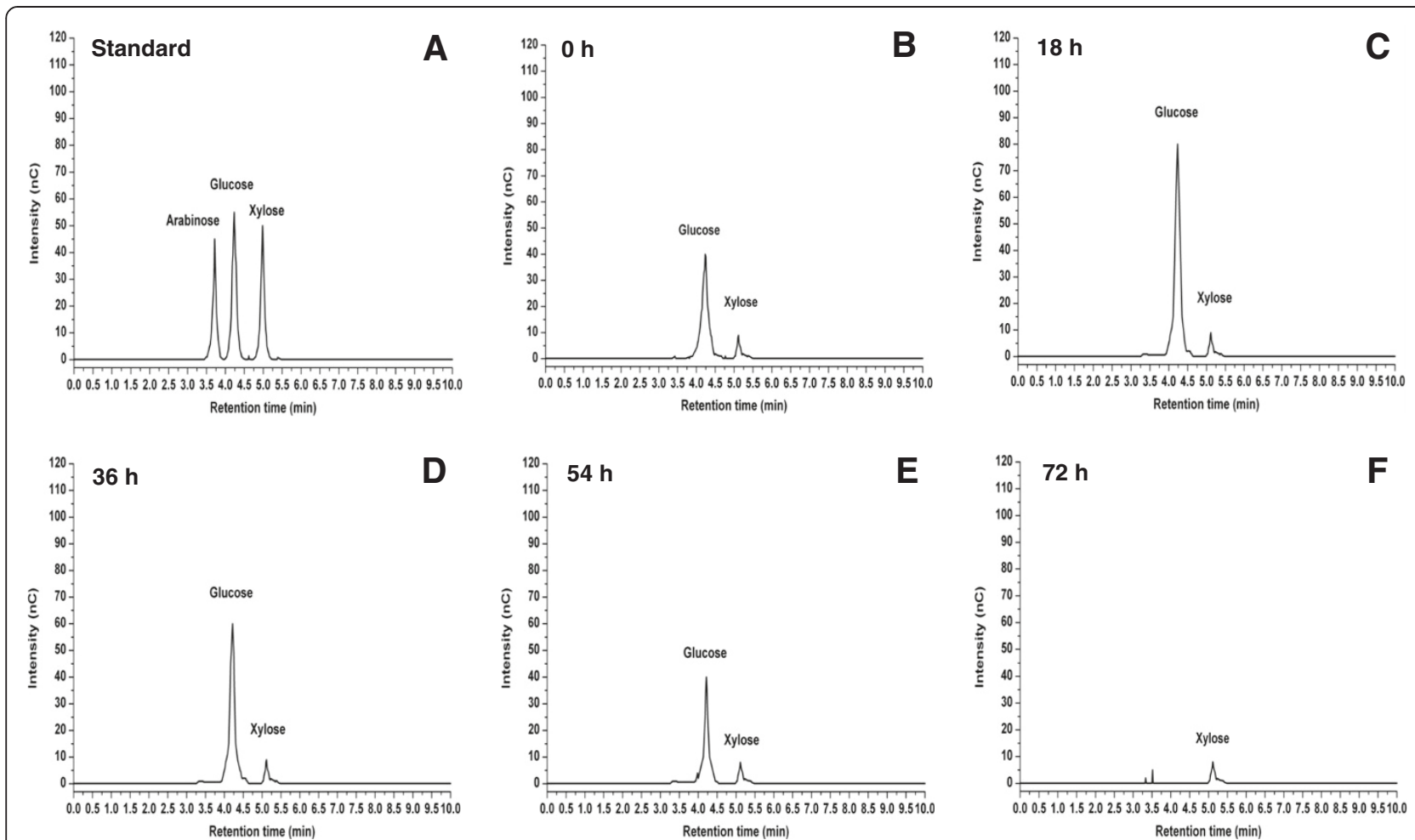

Figure 6 HPAEC profiles of monosaccharides obtained from bioreactor SSF of $5 \%\left(w^{-1}\right)$ thatch grass. The chromatogram of sugar hydrolysate viz., glucose and xylose were obtained at different time intervals by HPAEC-PAD (High pressure anion exchange chromatography pulsed amperometric detector) A) Standard containing arabinose, glucose and xylose B) 0 h C) 18 h D) 36 h E) 54 h F) 72 h.

ethanol g of substrate ${ }^{-1}$ ) (Table 3). Interestingly, the inverse relationship between reducing sugar concentration and specific activity of the enzyme was found to be more prominent in bioreactor as compared to shake flask level SSF.

The SSF profiles of various combinations implicated an interesting relation between the rate of saccharification, rate of sugar utilization and the rate of ethanol formation. A sinusoidal behavior was represented in most cases of the dynamic profile of reducing sugar depicting a balance between the rate of saccharification and utilization of sugar for growth and ethanol fermentation. In some cases, specifically, in bioreactor SSF, the accumulation of reducing sugar in the broth repressed activity of cellulase enzyme which in turn resulted in decreased rate of hydrolysis concluding the inverse relationship between the enzyme activity and the reducing sugar content. A glucose concentration of $20 \mathrm{~g} \mathrm{~L}^{-1}$ is reported to have $75 \%$ repressive effect on the cellulase activity [21]. Thus, the sinusoidal behaviour observed in all batch SSF experiments (Figures 3, 4 and 5) may be attributed to the combined effect of decrease of saccharification and in turn its subsequent utilization for growth and ethanol production. On the other hand, a sugar concentration below a threshold level decreased the repressive effect on cellulase activity. An interesting behaviour in our batch SSF experiments between depletion of sugars without any further rise in ethanol concentration indicated the utilization of sugars for maintenance and survival of the fermentative microbes (Figures 3, 4 and 5).

As compared to other fermentative microbes, $Z$. mobilis have shown better performance due to its potential of having high ethanol tolerance. In the present study, employing recombinant cellulase (GH5), in the ethanol titre (1.20 $\mathrm{g} \mathrm{L}^{-1}$ ) (Table 3), a 1.7-fold augmentation was noticed as compared to B. subtilis cellulase $\left(0.72 \mathrm{~g} \mathrm{~L}^{-1}\right)$ (Table 3$)$ and 1.3-fold escalation as compared to $T$. reesei cellulase (0.94 $\mathrm{g} \mathrm{L}^{-1}$ ) (Table 3) with $Z$. mobilis as the fermentative organism. This proves that the efficiency of thermostable recombinant $C$. thermocellum cellulases is higher over $B$. subtilis and T. reesei cellulases, due to having highest rates of cellulose utilization [9]. The best SSF combination of recombinant cellulase $(\mathrm{GH} 5)$ and $Z$. mobilis using $5 \%$ $\left(\mathrm{w} \mathrm{v}^{-1}\right)$ thatch grass at shake flask level yielded a 7.3-fold rise in ethanol titre and 1.5-fold higher ethanol yield as compared to $1 \%\left(\mathrm{w} \mathrm{v}^{-1}\right)$ substrate concentration. Moreover, when the shake flask SSF using $5 \%\left(\mathrm{w} \mathrm{v}^{-1}\right)$ thatch grass was scaled up in lab scale bioreactor a 2-fold upsurge both in ethanol titre and yield were obtained (Table 3). The controlled conditions of various parameters like aeration, $\mathrm{pH}$ in the bioreactor had an added advantage on the growth and ethanol titre [22]. An increase in the substrate concentration along with enzyme loadings and 
inoculum size had resulted in relative acceleration in ethanol titre and yield [23].

\section{Ethanol recovery with determination of purification process efficiency}

The crude ethanol obtained in SSF studies employing recombinant hydrolytic cellulase (GH5) and Z. mobilis using $5 \%\left(\mathrm{w} \mathrm{v}^{-1}\right)$ steam explosion pretreated thatch grass at bioreactor level was $20.44 \mathrm{~mL} \mathrm{~L}^{-1}$ i.e., $16.13 \mathrm{~g} \mathrm{~L}^{-1}$. The vacuum evaporation of fermentation broth $(1 \mathrm{~L})$ with crude ethanol yielded $4.80 \mathrm{~mL}$ of distillate comprising $4.53 \mathrm{~mL}$ i.e., $94.4 \%\left(\mathrm{v} \mathrm{v}^{-1}\right)$ of pure ethanol. Lastly, the purification process efficiency was found out to be $22.2 \%$. The residual ethanol in the broth obtained with the water condensates can be completely recuperated by numerous distillation steps as encompassed in large scale operations [14].

The ethanol titre and ethanol yield was found to be comparable with other reported values in the literatures. An ethanol concentration of $2.2 \mathrm{~g} \mathrm{~L}^{-1}$ was obtained from $1 \%\left(\mathrm{w} \mathrm{w}^{-1}\right)$ of banana waste using a coculture of Clostridium thermosaccharolyticum HG8 and Thermoanaerobacter ethanolicus ATCC 31937 [24]. An ethanol titre of $62.7 \mathrm{~g} \mathrm{~L}^{-1}$ ethanol using $19 \%\left(\mathrm{w} \mathrm{w}^{-1}\right)$ dry matter corncorb and commercial cellulolytic enzymes in bioreactor has been reported [23]. A SSF experiment involving 30\% $\left(\mathrm{w} \mathrm{w}^{-1}\right)$ solid content with commercial cellulase enzyme and Zymomonas mobilis as fermentative organism gave an ethanol concentration of $60 \mathrm{~g} \mathrm{~L}^{-1}$ [13]. One percent $\left(\mathrm{w} \mathrm{v}^{-1}\right)$ Mangifera indica leaves with recombinant $C$. thermocellum GH43 hemicellulase and Candida shehatae yielded an ethanol titre of $2.1 \mathrm{~g} \mathrm{~L}^{-1}$ [25]. The leafy biomass of mango contributed an ethanol titre of $12.3 \mathrm{~g} \mathrm{~L}^{-1}$ using naturally isolated cellulase and recombinant enzymes from $C$. thermocellum [26]. Z. mobilis upon fermentation of $20 \%\left(\mathrm{w} \mathrm{v}^{-1}\right)$ sugarcane bagasse resulted in an ethanol titre of $6.24 \mathrm{~g} \mathrm{~L}^{-1}$ and yield of $79 \%$ with productivity of $3.04 \mathrm{~g} \mathrm{~L}^{-1} \mathrm{~h}^{-1}$ [27].

This illustrates that in our SSF studies, a better choice of bioethanol production was provided by economically feasible recombinant (GH5) cellulase along with Zymomonas mobilis.

\section{Conclusions}

Effective steam explosion pretreatment released substantial hexose sugars from lignocellulosic thatch grass as confirmed by FT-IR studies. The recombinant GH5 cellulase with $1 \%\left(\mathrm{w} \mathrm{v}^{-1}\right)$ substrate and $Z$. mobilis in shake flask SHF and SSF trials demonstrated highest ethanol titre as compared to Bacillus subtilis and Trichoderma reesei cellulases. A $5 \%\left(\mathrm{w} \mathrm{v}^{-1}\right)$ substrate with recombinant enzyme in shake flask SSF resulted in a 7-fold increment of ethanol titre. The subsequent scale up in a $2 \mathrm{~L}$ bioreactor with $1 \mathrm{~L}$ working volume yielded a 2 -fold upturn both in ethanol titre and yield. The rotary evaporator based product recovery from bioreactor contributed
94.4 $\left(\%, \mathrm{v} \mathrm{v}^{-1}\right)$ pure ethanol with purification process efficiency of $22.2 \%$. SSF processes utilizing recombinant C. thermocellum enzymes have the prospective of yielding a value-added product, bioethanol with the curtailment of the production costs in industry.

\section{Methods}

\section{Reagents and substrate}

Ampicillin and components for LB and GYE media and other reagents of analytical grade were procured from Merck and Himedia laboratories (India). Carboxymethylcellulose (low viscosity, 50-200 cP) was purchased from Sigma Aldrich (St. Louis, USA). Lignocellulosic biomass thatch grass (Hyparrhenia rufa) collected from Guwahati, Assam, India was used as the substrate for SSF study. The substrate was pretreated by steam explosion for improved hydrolysis [28]. One gram of the powdered cellulosic substrate was taken in $250 \mathrm{~mL}$ Erlenmeyer flask. The mixture was autoclaved at $15 \mathrm{psi}$ and $121^{\circ} \mathrm{C}$ for $1 \mathrm{~h}$ followed by sudden steam depressurization by fully opening the steam exhaust valve.

\section{Microorganisms and culturing conditions}

Trichoderma reesei (MTCC 164) and Zymomonas mobilis (MTCC 2427) were procured from IMTECH, Chandigarh, India. Bacillus subtilis AS3 (Genebank accession No. EU 754025) isolated from cowdung was a gift from Professor Dinesh Goyal, Thapar University, Patiala, India. The recombinant family 5 glycoside hydrolase (GH5) gene was cloned and expressed earlier by the corresponding author AG as reported elsewhere [29] and is now also commercially available with NZY Tech, Lda, Lisbon, Portugal.

One millilitre of $T$. reesei spore suspension $\left(5 \times 10^{7}\right.$ spores $\mathrm{mL}^{-1}$ ) was inoculated to $100 \mathrm{~mL}$ of Potato Dextrose Broth and incubated at $28^{\circ} \mathrm{C}, 120 \mathrm{rpm}$ for $48 \mathrm{~h}$. The culture broth was then centrifuged at $10,000 \mathrm{~g}$ for 15 min and the cell free supernatant obtained was filtered twice and $1 \mathrm{~mL}$ of the filtrate was used as the crude enzyme for SSF experiment. The inoculum of $Z$. mobilis was prepared by growing the strain in the medium containing (g $100 \mathrm{~mL}^{-1}$ ): glucose 2; yeast extract $1 ; \mathrm{KH}_{2} \mathrm{PO}_{4}$ 0.2 . The $\mathrm{pH}$ was adjusted to 6 and incubated at $30^{\circ} \mathrm{C}, 120$ rpm for 48 h. $1 \mathrm{~mL}$ of actively growing aerobic culture $\left(2.1 \times 10^{6}\right.$ cells $\left.\mathrm{mL}^{-1}\right)$ was transferred to the fermentation media. B. subtilis inoculum was prepared by transferring a loop full of culture from nutrient agar slant in $5 \mathrm{~mL}$ of nutrient broth and incubated for $18 \mathrm{~h}$ at $37^{\circ} \mathrm{C}$ and 180 $\mathrm{rpm} .2 \%\left(\mathrm{v} \mathrm{v}^{-1}\right)$ of the fresh inoculum was transferred to $50 \mathrm{~mL}$ of the optimised medium containing $\left(\mathrm{g} \mathrm{L}^{-1}\right)$ : CMC, 18; peptone, 8; yeast extract, $5 ; \mathrm{K}_{2} \mathrm{HPO}_{4}, 1$; $\mathrm{MgSO}_{4} .7 \mathrm{H}_{2} \mathrm{O}, 0.25$; and $\mathrm{NaCl}, 5$ [8] in $250 \mathrm{~mL}$ Erlenmeyer flask and incubated at $37^{\circ} \mathrm{C}$ for $48 \mathrm{~h}$ followed by centrifugation at $10,000 \mathrm{~g}$ for $15 \mathrm{~min}$ at $4^{\circ} \mathrm{C}$. The cell free supernatant was used as the crude enzyme for saccharification. 
Recombinant E. coli BL21 cells transformed with plasmid containing Glycoside hydrolase family 5 gene from Clostridium thermocellum inserted in an expression vector pET21a [29] was used as source of recombinant cellulase enzyme. These cells are maintained in LB medium with $100 \mu \mathrm{g} \mathrm{mL} \mathrm{m}^{-1}$ ampicillin as glycerol stock at $-80^{\circ} \mathrm{C}$ in our laboratory at IIT Guwahati.

\section{Production of recombinant cellulase (GH5)}

$1 \%\left(\mathrm{v} \mathrm{v}^{-1}\right)$ of the E. coli $\mathrm{Bl}-21$ cells harbouring recombinant cellulase (GH5) from glycerol stock were inoculated into $5 \mathrm{~mL}$ of $\mathrm{LB}$ medium containing $100 \mu \mathrm{g} \mathrm{mL} \mathrm{m}^{-1}$ ampicillin and incubated at $37^{\circ} \mathrm{C}$ for $16 \mathrm{~h}$ at $180 \mathrm{rpm}$. $1 \%$ $\left(\mathrm{v} \mathrm{v}^{-1}\right)$ of the culture inoculum was transferred to 250 $\mathrm{mL}$ of LB medium in $500 \mathrm{~mL}$ flask containing $100 \mu \mathrm{g}$ $\mathrm{mL}^{-1}$ ampicillin and was incubated at $37^{\circ} \mathrm{C}, 180 \mathrm{rpm}$ till the culture reached to mid-exponential phase $\left(\mathrm{A}_{600} 0.6\right)$. Isopropyl- $\beta$-D-thiogalactopyranoside (IPTG) was added to this mid-exponential phase culture to a final concentration of $1 \mathrm{mM}$ followed by further $8 \mathrm{~h}$ incubation for protein induction. The cells were collected by centrifugation $\left(9,000 \mathrm{~g}, 4^{\circ} \mathrm{C}, 15 \mathrm{~min}\right)$ and were resuspended in $50 \mathrm{mM}$ sodium acetate buffer adjusted to $\mathrm{pH}$ 5.2. The recombinant enzyme was expressed as soluble protein. The cell extract containing soluble enzyme was sonicated in an ice bath for $15 \mathrm{~min}$ followed by centrifugation $\left(13,000 \mathrm{~g}, 4^{\circ} \mathrm{C}, 30 \mathrm{~min}\right)$. The supernatant was used as the enzyme source for SSF experiment.

\section{Separate hydrolysis and fermentation (SHF) at shake flask level}

Three individual batch separate hydrolysis and fermentation (SHF) experiments were carried out at shake flask level employing $1 \mathrm{~g}$ of steam explosion pretreated thatch grass (Hyparrhenia rufa). The fermentation medium contained $100 \mathrm{~mL}$ of $20 \mathrm{mM}$ sodium acetate buffer $(\mathrm{pH} 4.3$ ) in three separate $250 \mathrm{~mL}$ Erlenmeyer flasks. One millilitre of B. subtilis cellulase $\left(3.3 \mathrm{U} \mathrm{mg}^{-1}, 0.5 \mathrm{mg} \mathrm{mL}^{-1}\right), 0.3 \mathrm{~mL}$ of crude $T$. reesei cellulase (12.9 $\mathrm{U} \mathrm{mg}^{-1}, 0.82 \mathrm{mg} \mathrm{mL}^{-1}$ ) and $0.6 \mathrm{~mL}$ of crude recombinant cellulase (GH5) (5.6 $\mathrm{U} \mathrm{mg}^{-1}, 0.44 \mathrm{mg} \mathrm{mL}^{-1}$ ) for saccharification were added to each of the three flasks. The saccharification of the thatch grass was carried out at $50^{\circ} \mathrm{C}$ and $120 \mathrm{rpm}$ for $36 \mathrm{~h}$. Then, centrifugation of each medium was performed at $5,476 \mathrm{~g}$, $25^{\circ} \mathrm{C}$ for $15 \mathrm{~min}$ and the supernatant was collected separately. The supernatant was supplemented with $(0.1 \%$, $\mathrm{w} \mathrm{v}^{-1}$ ) each of yeast extract and peptone and used as fermentation medium separately for each of the SHF trials.

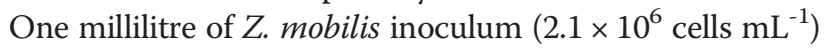
was inoculated to each of the flasks containing the fermentation medium. The fermentation was carried out for 3 days at $30^{\circ} \mathrm{C}$ and $120 \mathrm{rpm}$. The SHF parameters viz., cell OD at $600 \mathrm{~nm}$, ethanol concentration $\left(\mathrm{g} \mathrm{L}^{-1}\right)$, reducing sugar $\left(\mathrm{g} \mathrm{L}^{-1}\right)$ and specific activities $\left(\mathrm{U} \mathrm{mg}^{-1}\right)$ were estimated with collection of samples $(2 \mathrm{~mL})$ at every $6 \mathrm{~h}$ interval.

\section{Simultaneous saccharification and fermentation (SSF) at shake flask level}

In the first step, the performance of three different hydrolytic enzymes was compared from SSF experiments by growing $Z$. mobilis on steam exploded thatch grass as substrate. The comparative SSF studies were performed using $1 \%\left(\mathrm{w} \mathrm{v}^{-1}\right)$ steam exploded thatch grass in a 250 $\mathrm{mL}$ Erlenmeyer flask at $30^{\circ} \mathrm{C}$ and $120 \mathrm{rpm}$ till $72 \mathrm{~h}$ with sample collection at every 6 h. $1 \mathrm{~mL}$ of $Z$. mobilis $(2.1 \times$ $10^{6}$ cells $\mathrm{mL}^{-1}$ ) was employed for bioethanol production. The fermentation media containing $100 \mathrm{~mL}$ of $20 \mathrm{mM}$ sodium acetate buffer and supplemented with $0.1 \%\left(\mathrm{w} \mathrm{v}^{-1}\right)$ each of yeast extract and peptone was maintained at an initial $\mathrm{pH}$ of 4.3 in each batch of SSF. The first SSF combination comprised of $1 \mathrm{~mL}$ of $B$. subtilis cellulase (3.3 $\mathrm{U} \mathrm{mg}^{-1}, 0.5 \mathrm{mg} \mathrm{mL}^{-1}$ ) for hydrolysis and $1 \mathrm{~mL}$ of $Z$. mobilis for fermentation. The next combination involved $0.3 \mathrm{~mL}$ of crude $T$. reesei cellulase $\left(12.9 \mathrm{U} \mathrm{mg}^{-1}, 0.82 \mathrm{mg} \mathrm{mL}^{-1}\right.$ ) as the hydrolytic enzyme along with $1 \mathrm{~mL}$ of $Z$. mobilis as the fermentative organism. The final combination involved $0.6 \mathrm{~mL}$ of crude recombinant cellulase (GH5) $\left(5.6 \mathrm{U} \mathrm{mg}^{-1}\right.$, $0.44 \mathrm{mg} \mathrm{mL}^{-1}$ ) for saccharification alongwith $1 \mathrm{~mL}$ of $Z$. mobilis inoculum as the bioethanol producer. The dynamic profile of the SSF was obtained by estimating various fermentation parameters like cell OD, ethanol titre $\left(\mathrm{g} \mathrm{L}^{-1}\right)$, reducing sugar concentration $\left(\mathrm{g} \mathrm{L}^{-1}\right)$ and specific activity of enzyme $\left(\mathrm{U} \mathrm{mg}^{-1}\right)$.

\section{SSF experiment involving recombinant cellulase (GH5) and $Z$. mobilis with $5 \%\left(\mathrm{w} \mathrm{v}^{-1}\right)$ substrate in shake flask and bioreactor}

In the next step, a higher substrate concentration 5\% $\left(\mathrm{w} \mathrm{v}^{-1}\right)$ of pretreated thatch grass was used for best SSF combination involving recombinant cellulase (GH5) and Z. mobilis. $5 \mathrm{~mL}$ of crude recombinant cellulase (GH5) (5.6 $\mathrm{U} \mathrm{mg}^{-1}, 0.44 \mathrm{mg} \mathrm{mL}^{-1}$ ) for hydrolysis and $5 \mathrm{~mL}$ of Z. mobilis inoculum $\left(2.1 \times 10^{6}\right.$ cells $\left.\mathrm{mL}^{-1}\right)$ as the fermentative microbe were used for batch SSF at shake flask level. The fermentation medium containing $100 \mathrm{~mL}$ of $20 \mathrm{mM}$ sodium acetate buffer and supplemented with $0.1 \%\left(\mathrm{w} \mathrm{v} \mathrm{v}^{-1}\right)$ each of yeast extract and peptone was maintained at an initial $\mathrm{pH}$ of 4.3. Finally, bioethanol production in batch mode was scaled up in a $2 \mathrm{~L}$ capacity bioreactor (Applicon, Bio Console ADI 1025) with a working volume of $1 \mathrm{~L}$ sodium acetate buffer $(20 \mathrm{mM}$, $\mathrm{pH}$ 4.3) supplemented with yeast extract $\left(0.1 \%, \mathrm{w} \mathrm{v}^{-1}\right)$ and peptone $\left(0.1 \%, \mathrm{w} \mathrm{v}^{-1}\right) .5 \%\left(\mathrm{w} \mathrm{v}^{-1}\right)$ of steam exploded thatch grass was used as substrate for SSF studies. 50 $\mathrm{mL}$ of isolated crude recombinant cellulase (GH5) (5.6 $\mathrm{U} \mathrm{mg}^{-1}, 0.44 \mathrm{mg} \mathrm{mL}^{-1}$ ) was used for saccharification alongwith $50 \mathrm{~mL}$ of $Z$. mobilis inoculum $\left(2.1 \times 10^{6}\right.$ cells 
$\mathrm{mL}^{-1}$ ) for bioethanol production. The SSF parameters of $120 \mathrm{rpm}$ agitation, temperature of $30^{\circ} \mathrm{C}$ and $1 \mathrm{vvm}$ aeration rate were maintained by a mass flow controller. The cell growth was monitored by a spectrophotometer (Varian, Cary 50, Australia) at $600 \mathrm{~nm}$. The online process parameters like temperature $\left({ }^{\circ} \mathrm{C}\right), \mathrm{pH}$ and stirring rate $(\mathrm{rpm})$ were recorded for every $1 \mathrm{~min}$. The various offline parameters such as cell OD, reducing sugar $\left(\mathrm{g} \mathrm{L}^{-1}\right)$, specific activity $\left(\mathrm{U} \mathrm{mg}^{-1}\right)$ and ethanol content $\left(\mathrm{g} \mathrm{L}^{-1}\right)$ were obtained at every sampling time point of $6 \mathrm{~h}$. The trends of $\mathrm{pH}$ values are qualitative indicators of phenomenon like organic acid production or consumption. The $\mathrm{pH}$ was maintained at 4.3 by addition of $1 \mathrm{~N} \mathrm{HCl}$ and $1 \mathrm{~N} \mathrm{NaOH}$. Thus, owing to the sensitivity of the organism $\mathrm{pH}$ excursions below 4.3 were not permitted.

\section{Recovery of ethanol}

The crude bioethanol in $1 \mathrm{~L}$ of fermentation broth was filtered by Whatman filter paper 1 with the subsequent concentration of the filtrate in a rotary vaccum evaporator (Buchi Rotavapor R-200, Switzerland). A 2 L round bottom evaporation flask was used to heat $1 \mathrm{~L}$ fermentation broth at $78.5^{\circ} \mathrm{C}$ for $3 \mathrm{~h}$ in a water bath (Buchi Heating Bath B-490). Finally, the pure ethanol in the distillate was collected and analysed by dichromate method [30] as described later.

The purification process efficiency of ethanol by rotary vaccum evaporator was calculated by the following equation,

$$
\begin{aligned}
& \text { Purification process efficiency }(\%) \\
& =\frac{\text { volume of pure ethanol in distillate }\left(\mathrm{mL} \mathrm{L}^{-1}\right)}{\text { crude ethanol in fermentation broth }\left(\mathrm{mL} \mathrm{L}^{-1}\right)} \\
& \quad \times 100
\end{aligned}
$$

\section{Analytical methods \\ Structural carbohydrates estimation}

Cellulose, hemicellulose and lignin were determined by standardized methods of NREL, USA [31]. $0.3 \mathrm{~g}$ of cellulosic substrate (leafy biomass) was mixed with $3 \mathrm{~mL}$ of $72 \%\left(\mathrm{v} \mathrm{v}^{-1}\right) \mathrm{H}_{2} \mathrm{SO}_{4}$ and incubated at $30^{\circ} \mathrm{C}$ for $1 \mathrm{~h}$. Then, 84 $\mathrm{mL}$ of distilled water was added to bring down the concentration of $\mathrm{H}_{2} \mathrm{SO}_{4}$ to $4 \%\left(\mathrm{v} \mathrm{v}^{-1}\right)$. This was further autoclaved at $121^{\circ} \mathrm{C}$ and 15 psi pressure for $1 \mathrm{~h}$ followed by vaccum filtration. The residue collected after filtration was weighed which is acid insoluble lignin. The $\mathrm{pH}$ of the collected filtrate was neutralized by addition of $1 \mathrm{M} \mathrm{CaCO}_{3}$. Finally, the filtrate was assayed for reducing sugar which is glucose from where cellulose is calculated $(1 \mathrm{~g}$ cellulose $=1.1 \mathrm{~g}$ of glucose). The remaining content was hemicellulose.

\section{Measurement of cell growth}

The cell growth during fermentation was estimated with the withdrawl of initial medium along with the pretreated substrate prior to inoculation as blank. Then, the fermentative microbe $Z$. mobilis was inoculated into the fermentation medium. With the advancement of SSF, the absorbance of the broth samples containing the substrate along with the microbial cells was measured against the above blank. The difference in absorbance $\left(\mathrm{OD}_{600 \mathrm{~nm}}\right)$ was measured as cell growth.

\section{FESEM analysis}

Field emission scanning electron microscopy (FESEM-Carl Zeiss, SIGMA VP instrument) was used for analyzing the destabilization of structural arrangements of thatch grass. $25 \mu \mathrm{L}$ of the untreated and steam exploded thatch grass $\left(0.05 \mathrm{~g} \mathrm{~L}^{-1}\right)$ were placed over the glass slide, dried and coated with gold film using a SC7620"Mini", Polaron Sputter Coater, Quorum Technologies, Newhaven, England and the images were analyzed under the microscope.

\section{FT-IR spectroscopy analysis}

Fourier transform infrared (FT-IR) spectroscopy analysis of untreated and steam exploded thatch grass was carried out in FT-IR spectrometer (Spectrum Two, Perkin Elmer, USA). The samples were pelleted by dispersing $1 \mathrm{mg}$ each of dried $\left(45^{\circ} \mathrm{C}\right.$ for $\left.18 \mathrm{~h}\right)$ untreated and pretreated thatch grass with $3 \mathrm{mg}$ of potassium bromide (Sigma, USA) in 1:3 ratio. Three replicate of the samples were prepared to increase the reproducibility of the analysis of samples. The samples were verified by 30 scans per sample in iteration with resolution $4 \mathrm{~cm}^{-1}$ and data interval $0.1 \mathrm{~cm}^{-1}$.

\section{Enzyme assay with determination of protein content}

The cellulase assay of Bacillus subtilis AS3 was carried out in $100 \mu \mathrm{L}$ of reaction mixture containing $1.3 \%\left(\mathrm{w} \mathrm{v}^{-1}\right)$ final concentration of CMC ( $65 \mu \mathrm{L}$ of $\left.2 \%, \mathrm{w} \mathrm{v}^{-1} \mathrm{CMC}\right)$ in $50 \mathrm{mM}$ glycine $\mathrm{NaOH}$ buffer $(\mathrm{pH} 9.2)$ and $35 \mu \mathrm{L}$ of cell free supernatant and incubated at $45^{\circ} \mathrm{C}$ for $10 \mathrm{~min}$. One unit (U) of cellulase activity is defined as the amount of enzyme that liberates $1 \mu$ mole of reducing sugar (glucose) per min at $50^{\circ} \mathrm{C}$. In case of crude recombinant GH5 and T. reesei, the cellulase assay was carried out by incubating the enzyme with $\mathrm{CMC}$ for $10 \mathrm{~min}$ at $50^{\circ} \mathrm{C}$. The reaction mixture $(100 \mu \mathrm{L})$ contained $10 \mu \mathrm{L}$ of enzyme and $1.0 \%$ $\left(\mathrm{w} \mathrm{v}^{-1}\right)$ final concentration of CMC in $20 \mathrm{mM}$ sodium acetate buffer ( $\mathrm{pH}$ 4.3). The cellulase activity was measured by estimating the liberated reducing sugar employing Nelson Somogyi procedure [32,33]. The absorbance was measured at $500 \mathrm{~nm}$ using a UV-visible spectrophotometer (Perkin Elmer, Model lambda-45) against a blank with D-glucose as standard. The protein concentration was determined by the Bradford method using bovine serum albumin (BSA) as standard [34] for all the three cellulases. 


\section{HPAEC analysis of cellulose hydrolyzed by recombinant cellulase}

The monosaccharide released by enzymatic degradation of cellulose from steam exploded thatch grass (Hyparrhenia rufa) during bioreactor SSF was detected by high pressure anion exchange chromatography (HPAEC) using CARBO PACK $^{\text {Tw }}$ PA-20 column (Dionex) following the method of Van Gool [35]. The instrument (ICS-3000, Dionex) with a loop size of $25.0 \mu \mathrm{L}$ and flow rate of $0.5 \mathrm{~mL} \mathrm{~min}^{-1}$ was maintained at $30^{\circ} \mathrm{C}$ throughout the study. The reducing sugars eluted by $100 \mathrm{mM} \mathrm{NaOH}$ were analyzed by pulsed amperometric detector (PAD) in tandem with Dionex (ICS-3000). The HPAEC profiles of the monosaccharide, glucose released by recombinant cellulase (GH5) from complex cellulose were studied at $0,18,36,54,72$ and $96 \mathrm{~h}$. The monosaccharides, arabinose, glucose and xylose $\left(1.2 \mathrm{mg} \mathrm{mL}{ }^{-1}\right.$ final concentration of each sugar in the standard mixture) were employed as standards. The centrifugation of the crude sample $(200 \mu \mathrm{L})$ diluted with ultrapure water $(400 \mu \mathrm{L})$ was carried out $\left(15,493 \mathrm{~g}, 25^{\circ} \mathrm{C}\right.$ and $15 \mathrm{~min}$ ). The supernatant (500 $\mu \mathrm{L}$ ) filtered through $0.2 \mu \mathrm{m}$ membrane was consequently injected into HPAEC-PAD. The retention time for standard monosaccharide sugars used were arabinose (3.71 $\mathrm{min})$, glucose (4.23 $\mathrm{min}$ ) and xylose (4.98 min), respectively as shown in Figure 6A.

\section{Gas chromatographic and dichromate analysis of ethanol} A flame ionization detector (GC-FID, Varian 450) along with Porapaq column (Hayesep) Q $(3.0 \mathrm{~m} \times 2.0 \mathrm{~mm}$ i.d., 80-100 mesh, manufactured by Varian) was employed to perform the gas chromatographic analysis of ethanol [36]. The carrier gas used was nitrogen at a constant flow rate of $55 \mathrm{~cm}^{3} \mathrm{~min}^{-1}$. The oven temperature was kept at $150^{\circ} \mathrm{C}$ for 20 minutes isothermally. The injection volume used for analysis was $1 \mu \mathrm{L}$ along with the injector and detector temperature maintained at $170^{\circ} \mathrm{C}$.

For ethanol content estimation, dichromate method was also castoff where ethanol produced was converted to acid by reaction with dichromate [30]. The cell free culture was diluted 10 times (reaction volume $10 \mathrm{~mL}$ ) to which $2 \mathrm{~mL}$ of $\mathrm{K}_{2} \mathrm{Cr}_{2} \mathrm{O}_{7}\left(3.37 \mathrm{~g} 100 \mathrm{~mL}^{-1}\right)$ was added and absorbance was measured at $600 \mathrm{~nm}$.

\footnotetext{
Abbreviations

SHF: Separate hydrolysis and fermentation; SSF: Simultaneous saccharification and fermentation; H. rufa: Hyparrhenia rufa; T. reesei: Trichoderma reesei; B. subtilis: Bacillus subtilis; C. thermocellum: Clostridium thermocellum; GH5: Glycoside hydrolase family 5; Z. moblilis: Zymomonas mobilis; $\mathrm{g} \mathrm{L}^{-1}$ : Gram per litre; FT-IR: Fourier transform infrared spectroscopy; $\mu_{m}$ : Specific growth rate; HPAEC-PAD: High pressure anion exchange chromatography- pulsed amperometric detector; $A_{600}$ : Optical density at $600 \mathrm{~nm}$; GC: Gas chromatography; Yield of ethanol $\left(\mathrm{g} \mathrm{g}^{-1}\right)$ : Yield of ethano (gram of ethanol gram of substrate ${ }^{-1}$ ).
}

\section{Competing interests}

The authors declare that they have no competing interests.

\section{Authors' contributions}

SPD, DDe performed the experiments, analyzed the results, and wrote the manuscript. AGh contributed in FT-IR and HPAEC experiments. DD, MJ and AG designed the study, revised the manuscript, analyzed the results and contributed to writing of the manuscript. All authors read and approved the final manuscript.

\section{Acknowledgements}

Mr. Saprativ P. Das is supported by PhD fellowship from Indian Institute of Technology Guwahati through Ministry of Human Resource and Development (MHRD), Government of India, New Delhi, India The research work in part is supported by a project grant (BT/23/NE/TBP/2010) from Department of Biotechnology (DBT), Ministry of Science and Technology, New Delhi, India to Arun Goyal.

Received: 17 May 2013 Accepted: 2 September 2013

Published: 2 October 2013

\section{References}

1. Girio FM, Fonseca C, Carvalheiro F, Duarte LC, Marques S, Bogel-Łukasik R: Hemicellulose for fuel ethanol: a review. Bioresour Technol 2010, 10:4775-4800

2. Nada AAMA, El-Sakhawy M, Kamel SM: Infra-red spectroscopic study of lignins. Polym Degrad Stabil 1998, 60:247-251.

3. Kelley SS, Rowell RM, Davis M, Jurich CK, Ibach R: Rapid analysis of the chemical composition of agricultural fibers using near infrared spectroscopy and pyrolysis molecular beam mass spectrometry. Biomass Bioenerg 2004, 27:77-88.

4. Rodrigues FG, De Assunção RMN, Vieira JG, Meireles CS, Cerqueira DA, Barud HS, Ribeiro SJ, Messaddeq Y: Characterization of methylcellulose produced from sugar cane bagasse cellulose: crystallinity and thermal properties. Polym Degrad Stabil 2007, 92:205-210.

5. Rezende CA, Lima MA, Maziero P, Azevedo ER, Garcia W, Polikarpov I: Chemical and morphological characterization of sugarcane bagasse submitted to a delignification process for enhanced enzymatic digestibility. Biotechonol Biofuels 2011, 4:54.

6. Schulein M: Cellulases of Trichoderma reesei. Meth Enzymol Biomass Part A: Cellulose and Hemicellulose 1988, 160:234-242.

7. Maki M, Leung KT, Qin W: The prospects of cellulase-producing bacteria for the bioconversion of lignocellulosic biomass. Int J Biol Sci 2009, 5:500-516.

8. Deka D, Jawed M, Goyal A: Purification and characterization of an alkaline cellulase produced by Bacillus subtilis (AS3). Prep Biochem Biotechnol 2013, 43:256-270

9. Fontes CMGA, Gilbert HJ: Cellulosomes: highly efficient nanomachines designed to deconstruct plant cell wall complex carbohydrates. Annu Rev Biochem 2010, 79:655-681.

10. Mutreja R, Das D, Goyal D, Goyal A: Bioconversion of agricultural waste to ethanol by SSF using recombinant cellulase from Clostridium thermocellum. Enzym Res 2011. doi:10.4061/2011/340279.

11. Hamelinck CN, Hooijdonk GV, Faaij APC: Ethanol from lignocellulosic biomass: techno-economic performance in short-, middle- and longterm. Biomass Bioenerg 2005, 28:384-410.

12. Oyeleke SB, Jibrin NM: Production of bioethanol from guinea cornhusk and millet husk. Afr J Microbiol Res 2009, 3:147-152.

13. Santos DS, Camelo AC, Rodrigues KCP, Carlos LC, Pereira N Jr: Ethanol Production from sugarcane bagasse by Zymomonas mobilis using simultaneous saccharification and fermentation (SSF) process. Appl Biochem Biotechnol 2010, 161:93-105

14. Palmqvist E, Hahn-Haigerdal B, Galbe M, Larsson M, Zacchi G: Design and operation of a bench-scale process development unit for the production of ethanol from lignocellulosics. Bioresour Technol 1996, 58:171-179.

15. Li H, Kim NJ, Jiang M, Kang JW, Chang HN: Simultaneous saccharification and fermentation of lignocellulosic residues pretreated with phosphoric acid-acetone for bioethanol production. Bioresour Technol 2009, 100:3245-3251.

16. Mothe CG, Miranda IC: Characterization of sugarcane and coconut fibers by thermal analysis and FTIR. J Therm Anal Calorim 2009, 97:661-665.

17. Cao Y, Tan H: Structural characterization of cellulose with enzymatic treatment. Carbohydr Res 2002, 337:1291-1296. 
18. Pandey KK, Nagveni HC: Rapid characterization of brown and white rot degraded chir pine and rubberwood by FTIR spectroscopy. Eur J Wood Wood Prod 2007, 65:477-481

19. Meshitsuka G, Isogai A: Chemical structures of cellulose, hemicellulose and lignin. In Chemical modification of lignocellulosic materials. Edited by Hon DN. New York: Marcel Dekker Inc; 1996:11-34.

20. Adina C, Florinela F, Abdelmoumen T, Carmen S: Application of FTIR spectroscopy for a rapid determination of some hydrolytic enzymes activity on sea buckthorn substrate. Rom Biotech Lett 2010, 15:5738-5744.

21. Oh KK, Kim SW, Jeong YS, Hong SI: Bioconversion of cellulose into ethanol by nonisothermal simultaneous saccharification and fermentation. Appl Biochem Biotechnol 2000, 89:15-30.

22. Sebastian S, Vicente B, Eulogio C, Albert JM, Fernando C: The influence of $\mathrm{pH}$ and aeration rate on the fermentation of D-xylose by Candida shehatae. Enz Microb Technol 1997, 21:355-360.

23. Zhang M, Wang F, Su R, Qi W, He Z: Ethanol production from dry matter corncob using fed batch simultaneous saccharification and fermentation after combined pretreatment. Bioresour Technol 2010, 101:4959-4964.

24. Reddy HK, Srijana M, Reddy MD, Reddy G: Coculture fermentation of banana agro-waste to ethanol by cellulolytic thermophilic Clostridium thermocellum CT2. Afr J Biotechnol 2010, 9:1926-1934.

25. Das SP, Ravindran R, Ahmed S, Das D, Goyal D, Fontes CMGA, Goyal A: Bioethanol production involving recombinant $C$. thermocellum hydrolytic hemicellulase and fermentative microbes. Appl Biochem Biotechnol 2012, 167:1475-1488.

26. Das SP, Ravindran R, Deka D, Jawed M, Das D, Goyal A: Bioethanol production from leafy biomass of mango (Mangifera indica) involving naturally isolated and recombinant enzymes. Prep Biochem Biotechnol 2013, 43:717-734.

27. Wirawan F, Cheng CL, Kao WC, Lee DJ, Chang JS: Cellulosic ethanol production performance with SSF and SHF processes using immobilized Zymomonas mobilis. Applied Energy 2012, 100:19-26.

28. Sharma N, Kalra KL, Oberoi HS, Bansal S: Optimization of fermentation parameters for production of ethanol from kinnow waste and banana peels by simultaneous saccharification and fermentation. Ind I Microbiol 2007, 47:310-316.

29. Taylor EJ, Goyal A, Guerreiro CIPD, Prates JAM, Money VA, Ferry N, Morland C, Planas A, Macdonald JA, Stick RV, Gilbert HJ, Fontes CM, Davies GJ: How family 26 Glycoside Hydrolases orchestrate catalysis on different polysaccharides: structure and activity of a Clostridium thermocellum lichenase, Ctlic26A. J Biol Chem 2005, 280:32761-32767.

30. Seo HB, Kim HJ, Jung HK: Measurement of ethanol concentration using solvent extraction and dichromate oxidation and its application in bioethanol production process. J Ind Microbiol Biotechnol 2009, 36:285-292.

31. Sluiter B, Hames R, Ruiz C, Scarlata J, Sluiter D, Templeton D: Determination of structural carbohydrates and lignin in biomass. In Laboratory Analytical Procedure (LAP). Colorado: Technical Report NREL/ TP-510-42618; 2008.

32. Nelson N: A photometric adaptation of the Somogyi method for the determination of glucose. J Biol Chem 1944, 153:375-380.

33. Somogyi M: A new reagent for the determination of sugars. $J$ Biol Chem 1945, 160:61-68

34. Bradford MM: A rapid and sensitive method for quantitation of microgram quantities of protein utilizing the principle of protein-dye binding. Anal Biochem 1976, 72:248-254.

35. Van Gool MP, Vansco I, Schols HA, Toth K, Szakacs G, Gruppen H: Screening for distinct xylan degrading enzymes in complex shake flask fermentation supernatants. Bioresour Technol 2011, 102:6039-6047.

36. Bandaru WR, Somalanka SR, Mendu DR, Madicherla NR, Chityala A: Optimization of fermentation conditions for the production of ethanol from sago starch by co-immobilized amyloglucosidase and cells of Zymomonas mobilis using response surface methodology. Enz Microb Technol 2006, 38:209-214.

doi:10.1186/2043-7129-1-19

Cite this article as: Das et al:: Scale up and efficient bioethanol production involving recombinant cellulase (Glycoside hydrolase family 5) from Clostridium thermocellum. Sustainable Chemical Processes 2013 1:19.

\section{Publish with ChemistryCentral and every scientist can read your work free of charge \\ "Open access provides opportunities to our colleagues in other parts of the globe, by allowing anyone to view the content free of charge." \\ W. Jeffery Hurst, The Hershey Company. \\ - available free of charge to the entire scientific community \\ - peer reviewed and published immediately upon acceptance \\ - cited in PubMed and archived on PubMed Central \\ - yours - you keep the copyright \\ Submit your manuscript here: \\ http://www.chemistrycentral.com/manuscript/<smiles>c1ccccc1</smiles> \\ Chemistry Central}

